\title{
INSULAR GREAT BLUE HERON COLONIES ON LARGE MANITOBA LAKES
}

\author{
by Kees Vermeer, Canadian Wildlife Service, Edmonton
}

Island colonies of Great Blue Herons (Ardea herodias) were surveyed by float plane on large lakes (Fig. 1) in Manitoba in 1969. A few colonies may have been missed as the survey was not exhaustive.

The numbered colonies in Fig. 1 are identified in Table 1. Most of the heron colonies were found on islands in Lake Winnipegosis and adjacent lakes. The scarcity or absence of insular heronries in Lake Winnipeg may be related to the fact that the heron acquires its prey in marshes and shallow bays of which fewer were observed in Lake
Winnipeg than in Lake Winnipegosis and Lake Manitoba.

The mean heronry size consisted of 57 nests and ranged from 3 to 170 nests. This is a significantly higher average $(p<0.01)$ than that observed in heronries in Alberta in 1967, where the mean colony size was 21.3 and ranged from 1 to 55 nests (Vermeer, K. Can. Field-Nat., 83:237-242, 1969). Perhaps feeding conditions for herons at Lake Winnipegosis and adjacent lakes are more favourable than in Alberta.

The majority of nesting colonies

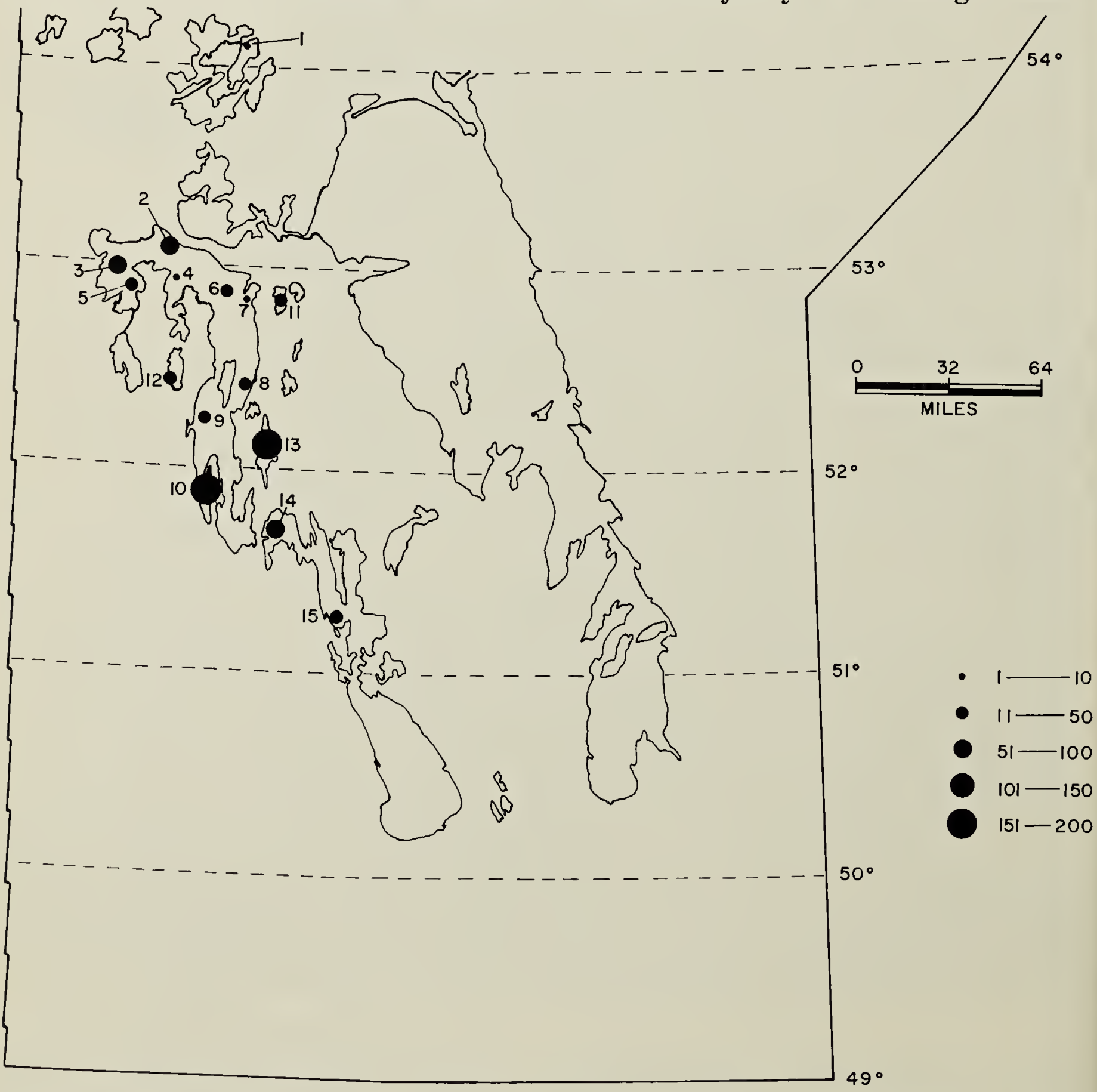

Fig. 1. Insular Great Blue Heron colonies on large Manitoba lakes. 
Table 1 Distribution and size of Great Blue Heron colonies on lake islands in Manitoba in 1969.

Colony location

1. Talbot Lake

$54^{\circ} 07^{\prime} \mathrm{N} \quad 99^{\circ} 53^{\prime} \mathrm{W} \quad 3^{*}$

Lake Winnipegosis

2. Reef north of North Long Island

3. Rowan Island

4. Hay Island

5. Mason Island

6. Cormorant Island

7. Island southeast of Denbeigh Point

8. Island southwest of Pigeon Island

9. Island south of South Camping Island

10. Sugar Island

11. Kawinaw Lake

12. Pelican Lake

13. Waterhen Lake

$53^{\circ} 04^{\prime} \mathrm{N} \quad 100^{\circ} 25^{\prime} \mathrm{W} \quad 80$

$52^{\circ} 58^{\prime} \mathrm{N} \quad 100^{\circ} 53^{\prime} \mathrm{W} \quad 80$

$52^{\circ} 55^{\prime} \mathrm{N} \quad 100^{\circ} 22^{\prime} \mathrm{W} \quad 9$

$52^{\circ} 55^{\prime} \mathrm{N} \quad 100^{\circ} 41^{\prime} \mathrm{W} \quad 45$

$52^{\circ} 52^{\prime} \mathrm{N} \quad 99^{\circ} 56^{\prime} \mathrm{W} \quad 26$

$52^{\circ} 49^{\prime} \mathrm{N} \quad 99^{\circ} 47^{\prime} \mathrm{W} \quad 4^{*}$

$52^{\circ} 25^{\prime} \mathrm{N} \quad 99^{\circ} 46^{\prime} \mathrm{W} \quad 45^{*}$

$52^{\circ} 15^{\prime} \mathrm{N} \quad 100^{\circ} 05^{\prime} \mathrm{W} \quad 35$

$51^{\circ} 52^{\prime} \mathrm{N} \quad 100^{\circ} 03^{\prime} \mathrm{W} \quad 170$

$52^{\circ} 50^{\prime} \mathrm{N} \quad 99^{\circ} 29^{\prime} \mathrm{W} \quad 25^{*}$

$52^{\circ} 25^{\prime} \mathrm{N} \quad 100^{\circ} 21^{\prime} \mathrm{W} \quad 48^{*}$

$52^{\circ} 07^{\prime} \mathrm{N} \quad 99^{\circ} 33^{\prime} \mathrm{W} \quad 160$

Lake Manitoba

14. North Twin Island $\quad 51^{\circ} 42^{\prime} \mathrm{N} \quad 99^{\circ} 27^{\prime} \mathrm{W} \quad 100$

15. Island northeast of Reykjavik $\quad 51^{\circ} 15^{\prime} \mathrm{N} \quad 98^{\circ} 58^{\prime} \mathrm{W} \quad 25^{*}$

Total number of nests

855

* Counted from the ground (others counted from the air)

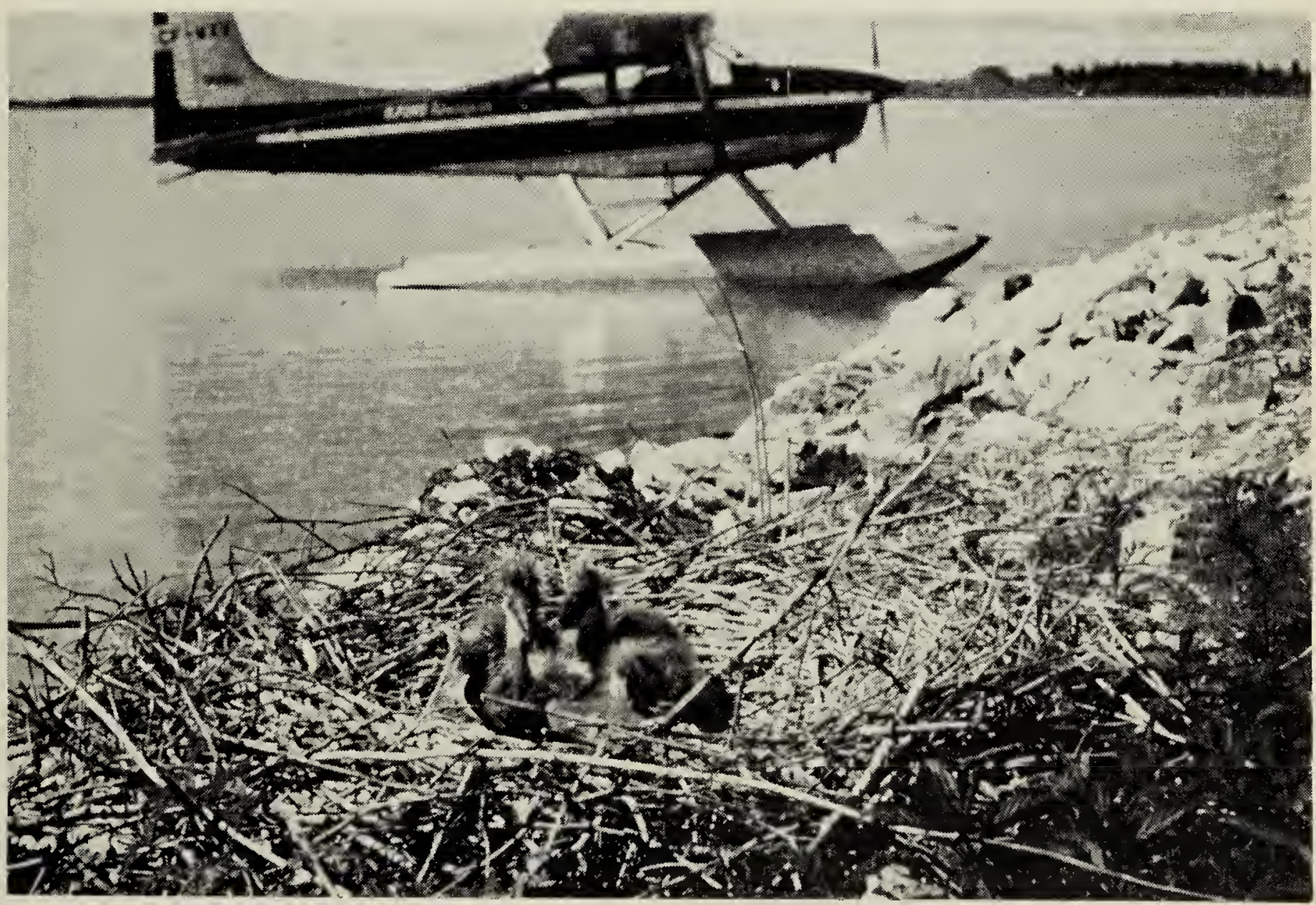

Fig. 2. Ground nest of Great Blue Fierons at Talbot Lake. 
were observed in elm (Ulmus americana) and box elder (Acer negundo) trees. In a heronry consisting of three nests at Talbot Lake, which was considerably north of the breeding range for Great Blue Herons as indicated by Godfrey (The birds of Canada, 1966), one nest was on the ground (Fig. 2) and the other two were elevated two feet in the only available red-osier dogwood (Cornus stolonifera) shrub. Double-crested Cormorants and White Pelicans nested on the same island as the herons in Talbot Lake. Two of four nests were also situated on the ground in a heronry within a Doublecrested Cormorant colony southeast of Denbeigh Point in Lake Winnipegosis. The other two nests were elevated five feet in the only available willow (Salix) bushes. It appeared that the birds in both heronries preferred to nest on the islands without trees rather than at any of the many suitable locations along the densely forested shore of the nearby mainland.

\section{AQUATIC BREEDING BIRDS OF THE ISLE OF BAYS, 1969}

\section{by Kees Vermeer, Canadian Wildlife Service, Edmonton}

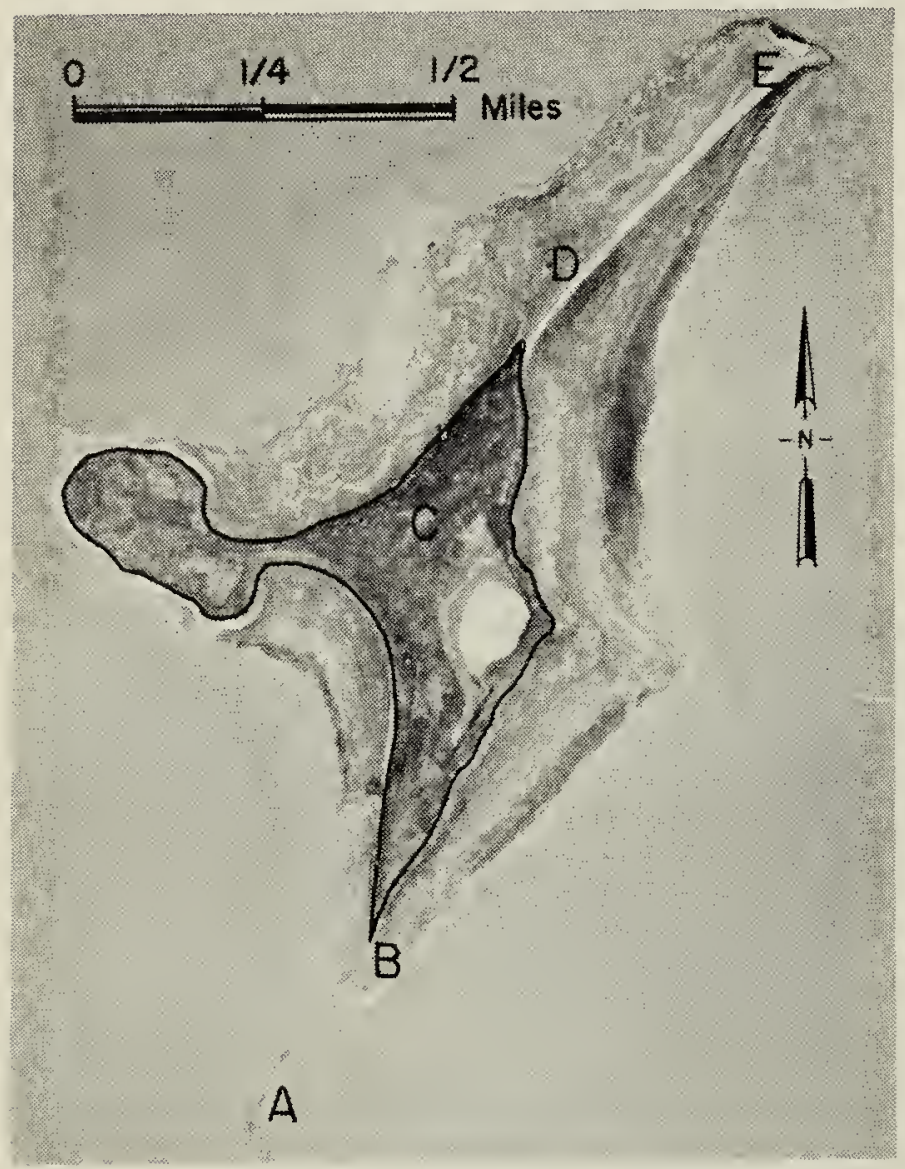

Fig. 1. Aerial photo of Isle of Bays, Old Wives Lake, 1965

A. Common Terns, 1969

B. Great Blue Herons, Double-Crested Cormorants and White Pelicans, 1957

C. Great Blue and Black-crowned Night Herons, 1969.

D. Double-crested Cormorants and White Pelicans, 1969.

D. California and Ring-billed Gulls, 1957, 1969.

E. Common Terns, 1957

Lahrman (Blue Jay, 15:106-109; 1957) described the bird life of an island, $50^{\circ} 07^{\prime} \mathrm{N} ; 105^{\circ} 55^{\prime} \mathrm{W}$, in Old Wives Lake, known as the Isle of Bays. I made some observations there on five days (May 14, 22, June 13, 14 and 26,1969$)$ while visiting the island to collect aquatic birds eggs for organochlorine residue analysis. Figure 1 shows a 1965 aerial photo of the 280 acre island; the insular configuration in 1969 was similar.

Numerous Ring-billed Gulls and several dozen California Gulls were observed nesting in region D (Fig. 1). Eighty-eight Double-crested Cormorant nests and 566 nests plus 200 large young of White Pelicans were also counted in that region on June 13. Five pairs of Great Blue Herons nested from 10 to 12 feet up in choke cherry (Prunus virginiana) bushes, while 415 nests with eggs and young of Black-crowned Night Herons were 2 to 10 feet elevated in those bushes in region $\mathrm{C}$ (Fig. 1). One hundred and forty Common Tern nests were found in the bare and rocky region A on June 14.

It appears that the gulls nested in the same area in 1969 as in 1957 , while the cormorants and pelicans moved to the other side of the island (Fig. 1). Great Blue Herons changed from nesting on the ground in region B in 1957 to the choke cherries in region $\mathrm{C}$. Lahrman did not observe Blackcrowned Night Herons nesting on the island in 1957, but states $(1957: 107)$ “... up to 50 or more could be seen at one time. They would fly back and forth to the mainland where they 